\title{
セルロースー不飽和脂肪酸系の油脂栃れによる 黄変に関する分光学的研究
}

\author{
岡.田仲子* ・藤井富美子** 一石川達 雄***。近藤 精一*** \\ * 梅花短期大学 (茨木市宿久庄 2-19-5) \\ ** 大阪市立大学生活科学部 (大阪市住吉区杉本町 3-3-138) \\ **** 大阪教育大学化学教室 (大阪市天王寺区南河堀町 4-88)
}

\begin{abstract}
A Spectroscopic Study of Yellowing Caused by Fatty Soil in a Cellulose-Unsaturated Fatty Acid System

Nakako OKadA*, Tomiko FujII**, Tatsuo IshirawA***, and Seiichi Kondo***

* Baika Junior College (Shukunosho, Ibaraki-shi)

** Faculty of Science of Living, Osaka City University (Sugimoto-cho, Sumiyoshi-ku, Osaka)

*** School of Chemistry, Osaka University of Education (Minamikawahoricho, Tennoji-ku, Osaka)
\end{abstract}

The mechanism of the yellowing of cellulose fibers caused by unsaturated tatty acıds such as oleic and linoleic acids was studied by IR and UV spectroscopy, using thin film of cellophane as a model fiber. The following conclusions were made.

(1) No chemical bonding occurs but a weak hydrogen-bond type interaction takes place between fatty acid and cellulose, and yellowing of cellophane itself is negligible.

(2) Yellowing of fatty acid is enhanced by higher temperature and light, but not so by oxygen gas, in contrast to nitrogen gas.

(3) No change in the absorbance of $\mathrm{C}-\mathrm{H}$ band attached to double bond takes place following strong yellowing.

(4) Yellowing is proportional to the increase in 204 and $210 \mathrm{~nm}$ bands which can be assigned to double bonds formed by polymerization of oleic and linoleic acids.

(5) Finally the main mechanism of yellowing reaction is not autoxidation but possibly kind of radical polymerization reaction of the double bonds of these fatty acids.

\section{1 緒言}

白色衣料を長期間繰り返し洗濯して着用していると， 纎維が次第に黄変してくる現象は, 日常しばしば経験さ れる。この主原因は, 繊維自体の化学変化のほかに, 洗 浄により除去されずに繊維上に残留蓄積している皮膚か ら分泌された不飽和化合物, とくにオレイン酸, トリオ レイン, スクアレン等の酸化重合によると言われてい

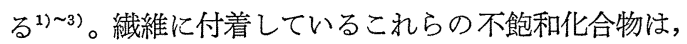
繊維上に広がり表面積が大きくなっているため, 酸化が 非常に速〈進行して黄変し ${ }^{4), 5)}$, その黄変の程度は繊維 基質の影響をうけると言われている。例えば，ポリエス テル布上にくらべて木綿布上で黄変しやすく, 黄変した ものは洗濯により除去されにく(い) 3)。さらに，不飽和

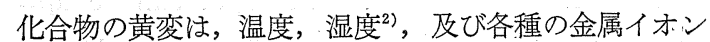
の存在(6) などによって促進される。しかしこれらの 現象の詳細な研究報告は少ない。 そこで本研究は, 不飽和化合物の変化による黄変の機 構，及びその䋊維基質との関係を明らかにするために， セロハンとオレイン酸をモデル材料としてセルロースと 不飽和脂肪酸との相互作用を検討し, さらに, セルロー ス基質上の不飽和脂肪酸の黄変に及ぼす雾囲気の影響を 分光学的方法を用いて検討した。

\section{2 実 験}

\section{1 試料}

不飽和脂肪酸は, オンイン酸 (純度 $99.6 \%$ ) 及びリ ノール酸 (純度 $99.3 \%$ )(いずれも日本油脂製)を使用し 
た。

セルロースは, 分光法に適した厚さ $13 \mu \mathrm{m}$ のセロハン (二村化学製) を用い，柔軟剤として 8〜25\% 含まれて いるグリセリン，エチレングリコールなどを除去するた めに $\mathrm{pH} 3$ の希硫酸中で $80^{\circ} \mathrm{C}$ で, $30 \mathrm{~min}, 2$ 回洗浄し た。この精製セロハンの灰分は $6.9 \mathrm{mg} / \mathrm{g}$, 比表面積は $0.8 \mathrm{~m}^{2} / \mathrm{g}$ (窒素吸着 $\mathrm{BET}$ 法) であった。

このセロハンを良く乾燥し, オレイン酸又はリノール 酸の $10 \%$ ベンゼン溶液中に浸漬した後, 空気中でベン ゼンを蒸発させた。脂肪酸付着量は, 約 $240 \mathrm{mg} / \mathrm{g}$ であ った。これらの試料について, 一定の温度下で酸素雾囲 気及び窒素雾囲気中で静置し，経時変化を見た。また， 種々の温度及び液相中で, セロハンとオレイン酸との相 互作用を見た。

\section{2 赤外・可視・紫外分光法}

近赤外領域の吸収スペクトルは, FT-NIR 分光光度計 FTS-15 E 型 (Digilab 製) により真空石英セルを用い て測定した。可視・紫外領域では自記分光光度計 UV240 (島津製作所製) を用いて空気中で測定した。

\section{3 結果と考察}

\section{$3 \cdot 1$ セロハン及びオレイン酸の IR スペクトル} 純セロハンの常温真空中でのIR スペクトルは, Fig。1 の実線に示すように $\mathrm{OH}$ 伸縮振動による 3,500〜3,200 $\mathrm{cm}^{-1}$ の広い吸収帯及び $\mathrm{CH}$ 伸縮振動による 2,900

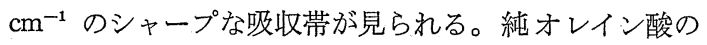
IR スペクトルには, 二重結合炭素の $\mathrm{CH}$ 伸縮振動によ る $3,005 \mathrm{~cm}^{-1}$, 及び単結合の $\mathrm{CH}$ 伸縮振動による 2,925 $\mathrm{cm}^{-1}$ 及び $2,850 \mathrm{~cm}^{-1}$ のシャープな吸収帯が見られる。

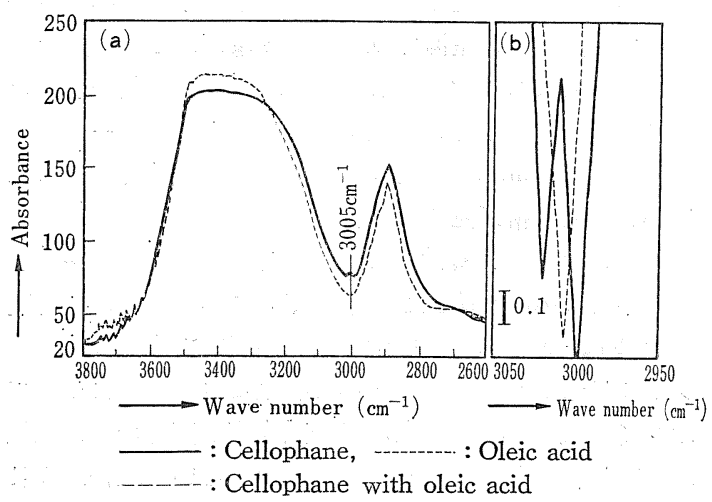

Fig.-1 IR spectra of cellophane and oleic acid.

セロハンにオレイン酸を付着させ, 直ちに常温真空中 で測定したスペクトルは，セロハン及びオレイン酸両者 の $\mathrm{CH}$ 伸縮振動吸収帯が重なり，2,900 $\mathrm{cm}^{-1}$ に極大を 示すやや大きい吸収となる。また，オレイン酸の 3,005 $\mathrm{cm}^{-1}$ の吸収が見られる。

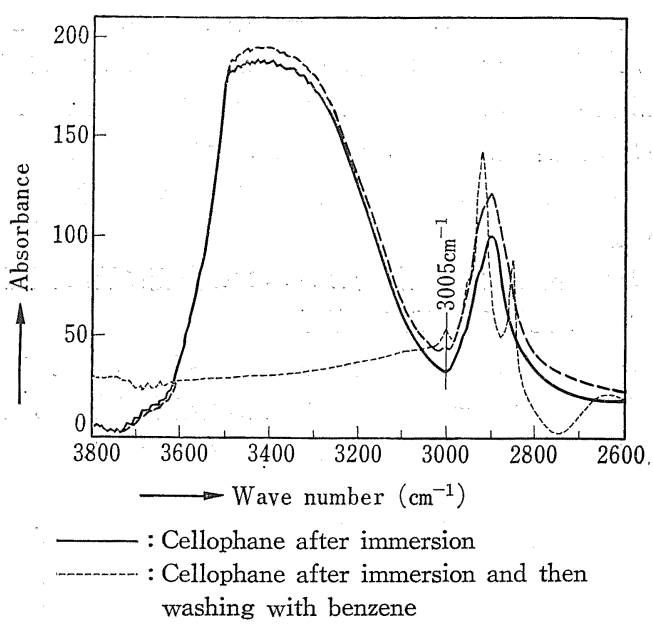

Fig.-2 (a) IR spectra of cellophanes immersed in $10 \%$ benzene solution of oleic acid at $50^{\circ} \mathrm{C}$ for $24 \mathrm{~h}$, and (b) shows the same spectrum with expanded wave number.

\section{2 セロハンとオレイン酸との相互作用}

黄変現象に及ぼす機構を解明する手がかりとして，セ ロハンとオレイン酸との吸着相互作用の検討を行った。

まず，オレイン酸 $10 \%$ ベンゼン溶液にセロハンを $50^{\circ} \mathrm{C}$ で $24 \mathrm{~h}$ 浸漬した後取り出し; そのままベンゼンを 蒸発させたもののスペクトルと, このものをベンゼン で 6 回洗浄後蒸発させたもののスペクトルを $\mathbf{F i g 。 - 2}$ (a) に示す。前者は， $3,005 \mathrm{~cm}^{-1}$ に吸収が認められる が，洗浄を充分したものはこの吸収が認められない。 $3,005 \mathrm{~cm}^{-1}$ 付近の吸収波数及び強度を拡大してみると， Fig.-2（b）に示すように後者の場合には，セロハンか らオレイン酸が完全に除去されていることが確認され た。このことから，セロハンに付着したオレイン酸は， セロハンの官能基とはこのような稻やかな条件では結合 せず，弱く物理的に付着しているものと考えられる。

次に,オンイン酸と, セロハンの $\mathrm{OH}$ 基とのエステル 化などによる化学結合の可能性を検討した。一般のエス テル化反応の触媒の一つとしての濃硫酸を，オレイン酸 $10 \%$ ベンゼン溶液に数 \% 加え, この中でセロハンを $20^{\circ} \mathrm{C}$ で $20 \mathrm{~min}$ 浸漬処理し, 純ベンゼンで洗浄し, 更 に水で洗浄した場合の IR スペクトルには，オレイン酸 の $3,005 \mathrm{~cm}^{-1}$ の吸収は認められなかったので，オレイ ン酸はこの方法ではセロハンに固定化されていないと考 えられる。この時液相中のオレイン酸は, セロハンの存 在しないときと同様に黄変していた。また，三フッ化ホ ウ素メタノール錯体を触媒としてオレイン酸ベンゼン溶 液に $20 \%$ 加え $80^{\circ} \mathrm{C}$ で $5 \mathrm{~min}$ セロ八ンを処理した場 合にも同様な結果が得られ，オレイン酸は反応しなかっ たことがわかる。

さらに, オレイン酸 $10 \%$ ベンゼン溶液中にセロハン 
を浸漬したものをオートクレーブ中で $200^{\circ} \mathrm{C}, 1 \mathrm{~h}$ 処理 した場合も，セロハンは黄変するが $3,005 \mathrm{~cm}^{-1}$ には吸 収が認められなかった。従って,オレイン酸またはセ口 ハンに黄変が生じても, セロハンとオレイン酸との間に はか酷な条件下でも化学反応は起こり難いと考光てょ (

\section{3 不飽和脂肪酸付着セロハンの黄变に及ぼす酸素 及び窒素䨌囲気の影響}

$3 \cdot 3 \cdot 1$ 純セロハンの近紫外吸収スペクトルの変化

もし，セルロースーオレイン酸系の黄変の原因が，空 気中の酸素による自動酸化であるとすれば1),10)，黄変は

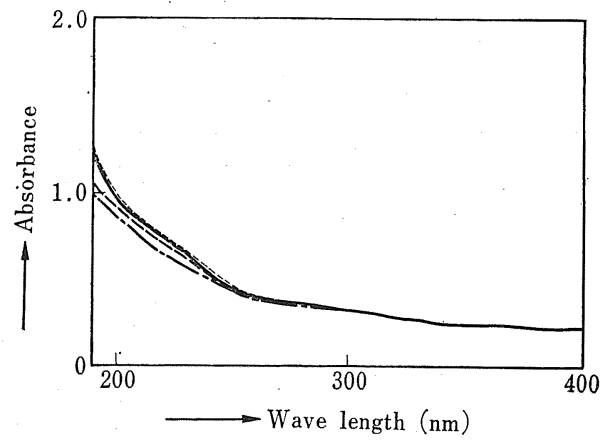

: Pure cellophane held in nitrogen gas : Pure cellophane held in oxygen gas : Cellophane with oleic acid held in oxygen gas

- - - : Pure cellophane without treatment

Fig.-3 UV spectra of cellophans after various treatment at $70^{\circ} \mathrm{C}$ for $10 \mathrm{~d}$.

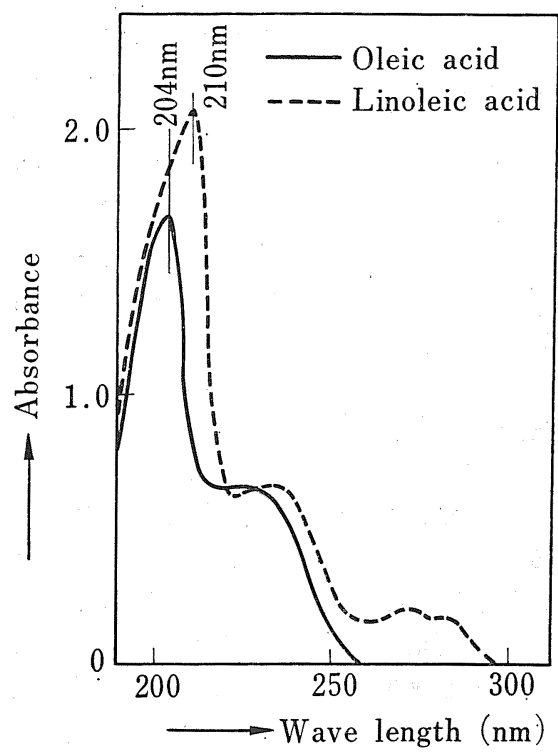

Fig.-4 UV spectra of cellophanes immediately after immersion to oleic and linoleic acid.

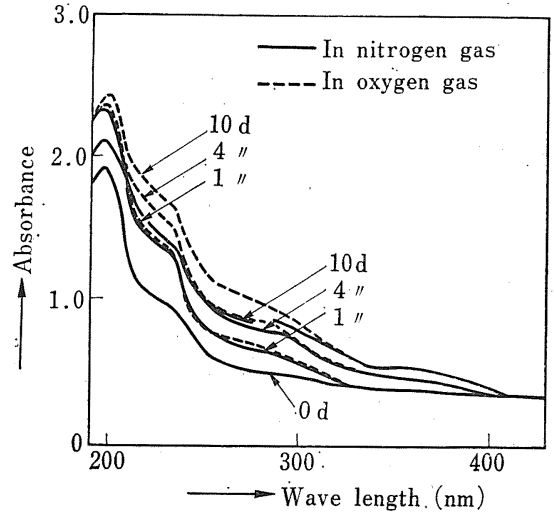

Fig.-5 UV spectra of cellophanes with oleic acid aged for days cited in each curve at $70^{\circ} \mathrm{C}$.

酸素雰囲気中で顕著に認められるはずである。そこで， 酸素または窒素雰囲気中でのオレイン酸及びリノール酸 付着セロハン及び純セロハンの経時変化を，主として 190 400 nm 領域の近紫外吸收スペクトルにより検討し た。Fig.-3 に示すスペクトルは, $70^{\circ} \mathrm{C}$ の密閉ガラス容 器に $10 \mathrm{~d}$ ，(1) 酸素雾囲気中で純セロハン，（2）窒素雾 囲気中で純セロハンを静置し，(3) 酸素雾囲気中でオレ イン酸付着セロハンを静置後メチルアルコールで完全に 洗浄したものである。未処理の試料と比較すると，(1)， (2)，（3）の吸光度はわずかしか変わらず，これらの条 件では純セロ八ンの黄変は起こらないことがわかった。

$3 \cdot 3 \cdot 2$ オレイン酸及びリノール酸付着セロハンの近 紫外吸収スペクトルの変化

オレイン酸及びリノール酸をセロハンに約 $240 \mathrm{mg} / \mathrm{g}$ 付着させた直後のものについて, これらの酸の近紫外吸 収スペクトルを，純セロハンを対照とする差スペクトル として, 空気中, 室温で測定し, Fig.-4 に示す。オレ イン酸の吸収スペクトルには，204 nm の吸収帯とその 肩に $235 \mathrm{~nm}$ の小さい吸収帯が見られる。リノール酸の それは, $210 \mathrm{~nm}$ の吸収帯と，235，275 及び $285 \mathrm{~nm}$ に小さい吸収帯が見られる。

次に, オレイン酸付着セロハンを $70^{\circ} \mathrm{C}$ で酸素中及び 窒素中で $10 \mathrm{~d}$ 静置した場合の吸収 スペクトルの経時変 化を Fig.-5 に示す。いずれの雾囲気中でも，吸収スペ クトルは末処理 $(0 \mathrm{~d})$ に比べて静置日数が増すにつれて オレイン酸の $235 \mathrm{~nm}$ 吸収帯の吸光度が高くなり, 未処 理の時は存在しなかった $285 \mathrm{~nm}$ の小さい吸收帯が 1 日 目から現れ，次いで $355 \mathrm{~nm}$ の吸収帯が 4 日目から現れ る。新たに見られた 285 及び $335 \mathrm{~nm}$ の吸収帯は, Fig.-3 の純セロハンの経時変化の吸収スペクトル (1), (2) 及びオレイン酸付着セロハンを洗浄したものの吸収 スペクトル（3）には観察されないことから，235，285， $355 \mathrm{~nm}$ の吸収帯の増大はオレイン酸の変化に基ら゙くも のであると考えられる。 


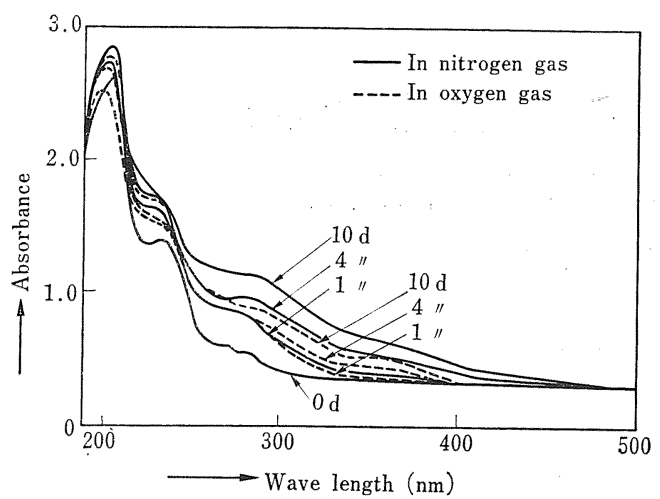

Fig.-6 UV spectra of cellophanes with linoleic acid aged for days cited in each curve at $70^{\circ} \mathrm{C}$.

酸素中のスペクトルの吸光度は, 窒素中のそれとほぼ 同程度である。いずれの場合も日数の増加に伴って可視 領域 (380 nm 以上) まで吸光度が増加してくる。

以上のことから,オレイン酸のスペクトルの変化は, 酸素による酸化が主原因ではなく,オレイン酸分子中の 二重結合のラジカル重合反応が主に起こり, 共役二重結 合をもつ物質が生成することを示すものと考えられる。 ただ, 酸素中の方がやや高い理由は, 酸素の存在によっ てラジカル重合と共に酸化重合も起こるためではないか と考えられる。

リノール酸付着セロハンを $70^{\circ} \mathrm{C}$ で酸素中及び窒素中 に静置した場合の吸収スペクトルを，Fig.-6 亿示す。 いずれの雰囲気中でもスペクトルの吸光度は, 未処理 (0d) に比べて高くなり，1日目から可視領域に広がっ て行く。355 nm の吸收帯も1日目から現れる。従って 吸収スペクトルの変化の程度はオレイン酸付着セロハン より著しい。これらの理由は, オレイン酸は1分子中に 1 個の二重結合を持つのに対してリノール酸は 2 個持っ ているためラジカル重合が進みやすいからであるう。な お, 窒素中の吸光度の経時変化の程度が酸素中のそれよ りも大きい事は, 酸素がラジカル反応を抑制しているこ とを示唆しているとも考光られ興味深い。この結果は， オレイン酸の場合と異なり, 今後の研究に待たねばなら ない。

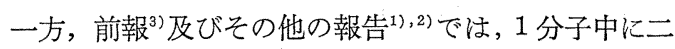
重結合の多い不飽和化合物の方が黄変速度が速いことが 認められている。黄変は吸収スペクトルに拉ける可視領 域の吸収に関係すると考えられるのでオレイン酸及びリ ノール酸の黄変を可視領域の吸収スペクトルの変化から 検討した。上記 (Fig.-5，-6) の酸素中及び窒素中での オレイン酸及びリノール酸付着セロハンの吸収スペクト ルの可視部 (380 nm 以上)の積分強度と静置日数の関

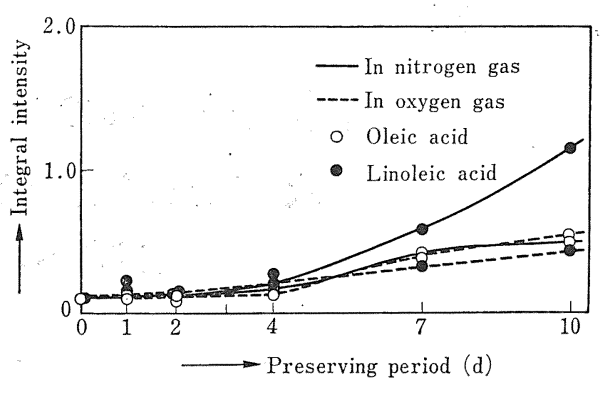

Fig.-7 The change of integral intensities of UV spectra of oleic and linoleic acids on cellophane against aging days at $70^{\circ} \mathrm{C}$.

係を Fig.-7 に示す。オレイン酸及びリノール酸付着セ ロハン共に $0 \mathrm{~d}$ ではその積分強度は 0.1 で, 静置日数 4 日目から徐々に増大し，ほとんど無色であったオンイン 酸, リノール酸の黄変が進んでいくことがわかる。黄変 は窒素中の場合の方が酸素中の場合に比べて著しいこと から, 不飽和脂肪酸の黄変の原因は, 主としてラジカル 重合に基づくものであると考えてよい。なお，二重結合 の 2 個のものの方が 1 個のものより黄変速度が速い。

\section{4 結論}

セルロース繊維製の衣料の黄変の原因は，1）主とし て, 不飽和脂肪酸がラジカル重合反応するためであると 考光られる，2）分泌された不飽和脂肪酸はセルロース とは容易に結合せず，七ロハン自身はほとんど黄変しな い。

本研究の一部は, 昭和 60,61 年度文部省科学研究費 (一般研究 C) により行った。

(昭和 60 年 11 月 5 日受理)

\section{文献}

1) 米田義章, 美濃順亮, 穴戸武雄, 油化学, 19, 232 (1970)

2) 柏 一郎, 桑村秀明, 稲森正和, 西沢 均, 角田光雄, 大場洋一, 加藤千春, 油化学, 20, 95 (1971)

3) 岡田仲子, 藤井富美子, 奥山春彦, 家政誌, 25, 216 (1974)

4) F. Franks, B. Roberts, J. Appl. Chem., 15, 109 (1965)

5）杉原黎子, 安藤久子, 藤谷 健, 家政誌, 33, 521 (1982)

6) M.S. Sontag, M.E. Purchase, B.F. Smith, Tex. Res. J., 40, 529 (1970)

7) M.A.J. Rounds, M.E. Purchase, B.F. Smith, Tex. Res. J., 43, 517 (1973)

8）岡田仲子, 藤井富美子, 奥山春彦, 家政誌, 27, 215 (1976)

9）祖父汇 寬, 右田伸彦, “セルローズハンドブック”, 朝倉 書店, 東京 (1958) p. 325

10) O.S. Privett, M.L. Blank, J.B. Covell, W.O. Lund= berg, J. Am. Oil Chem. Soc., 38, 22 (1961) 